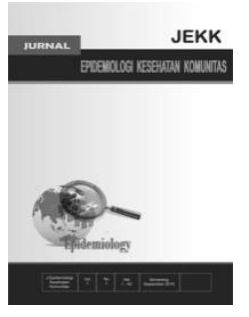

\title{
Faktor yang Berhubungan dengan Praktik Manajemen Terpadu Bayi Muda oleh Gasurkes KIA di Kota Semarang
}

\author{
Sinta Wati*, Apoina Kartini ${ }^{* *}$, Martini $^{* *}$, Ayun Sriatmi ${ }^{* *}$ \\ *Magister Epidemiologi, Sekolah Pascasarjana, Universitas Diponegoro, Semarang \\ ${ }^{* *}$ Fakultas Kesehatan Masyarakat Universitas Diponegoro, Semarang
}

\begin{abstract}
Background: The main causes of neonatal deaths in Semarang city were low birth weight (LBW) approximately 38\%, birth asphyxia (23\%), congenital defect (8\%), infections (3\%) and others $(25 \%)$. The most common causes of mortality were considered preventable and treatable at an affordable, easily-to-implement, and efficient through integrated management of young infants (IMYI) performed during neonatal visits. It has previously been observed that IMYI has contributed to reducing the neonatal mortality rate by $30-60 \%$. This study aims to investigate the factors that determine the integrated management of young infants carried by maternal and perinatal death surveillance and response (MPDSR) workers in Semarang city.

Methods: The research used quantitative analytic with a cross sectional approach.. Using a sample of 84 district maternal and perinatal death surveillance and response workers and a trial sample of 20 independent practicing midwives (PMB). Data collection used questionnaires, while data analyzed using chi-square, Fisher exact test, and logistic regression.

Results: The result suggests that knowledge, work period, attitude, workload, recording system, supervision had an association toward the practice of IMYI conducted by MPDSR workers in Semarang City. No significant correlation was found on the availability of tools and appraisal toward the practice of IMYI. Work periods was the most dominant factor affecting IMYI practice.

Conclusion: These results indicate that knowledge, work period, attitude, workload, recording system, supervision has an important role to increase the practice of IMYI performed by maternal and perinatal death surveillance and response (MPDSR) workers in Semarang city.
\end{abstract}

Keywords: IMYI practice; MPDSR workers; neonatal visits; neonatal mortality.

*Penulis korespondensi: sintw41@yahoo.com 


\section{Pendahuluan}

Salah satu parameter derajat kesehatan suatu negara adalah kematian ibu dan bayi. Jumlah Angka Kematian Ibu dan Bayi (AKI dan AKB) di Indonesia masih terbilang tinggi. Kematian neonatal juga menjadi salah satu indikator penentu kesehatan dan derajat kesehatan anak. Seluruh negara di dunia termasuk Indonesia menyetujui sebuah kerangka kerja pembangunan lanjutan yang baru yaitu Sustainable Development Goals (SDGs).SDGs merupakan sebuah kesepakatan pembangunan pengganti MDGs dengan masa berlaku 20152030 yang berisikan 17 goals dan 169 sasaran pembangunan.Kematian bayi dan balita merupakan salah satu indikator yang akan dipantau dalam pencapaian target Tujuan Pembangunan Berkelanjutan (SDGs) 2030. Target SDGs 2030 adalah mengakhiri kematian bayi dan balita yang dapat dicegah, dengan seluruh negara berusaha menekan Angka Kematian Neonatal setidaknya hingga 12 per 1000 kelahiran hidup. Berdasarkan data SDKI tahun 2017 menunjukkan bahwa kematian neonatal di Indonesia masih 15 per 1000 kelahiran hidup, kematian bayi 24 per 1000 kelahiran hidup. ${ }^{1}$

Berdasarkan hasil laporan kesehatan ibu dan anak jumlah kematian bayi di Kota Semarang Tahun 2016 ada 151 kasus kematian neonatal dari total 26.337 kelahiran hidup dengan Angka Kematian Neonatal (AKN) 5,73 per 1000 kelahiran hidup, sementara pada tahun 2017 tercatat 150 kasus kematian neonatal dari 26.052 kelahiran hidup dengan Angka Kematian Neonatal (AKN) 5,76 per 1000 kelahiran hidup di Tahun 2018 ada 124 kasus dari 25.074 kelahiran hidup dengan Angka Kematian Neonatal (AKN) 4,95 per 1000 kelahiran hidup dan Tahun 2019ada 119 kasus dari 23.746 kelahiran hidup dengan Angka Kematian Neonatal (AKN) 5,01 per 1000 kelahiran hidupyang artinya belum terdapat penurunan pada angka kematian neonatal selama kurun waktu tahun terakhir. ${ }^{2}$

Penyebab utama kematian neonatal di Kota Semarang yaitu bayi dengan berat lahir rendah (BBLR) sebesar 38\%, asfiksia (23\%), kelainan kongenital (8\%) dan infeksi seperti sepsis (3\%), ikterus ( $3 \%$ ) dan lain-lain $(25 \%)$. $^{2}$ Sebagian besar penyebab kematian tersebut merupakan kematian yang dapat dicegah dan diobati dengan biaya yang murah, mudah dan efektif melalui pendekatan Manajemen Terpadu Bayi Muda yang dilakukan pada saat kunjungan neonatal mempunyai kontribusi dalam menurunkan kematian neonatal sebesar $30-60 \%{ }^{3}$

Manajemen Terpadu Bayi Muda adalah bagian dari Manajemen Terpadu Balita Sakit yang merupakan pedoman tatalaksana untuk bayi muda kurang 2 bulan baik yang sehat maupun sakit di fasilitas kesehatan dasar. Penanganan bayi muda seharusnya dilakukan oleh bidan pada kunjungan neonatal dengan menggunakan pendekatan MTBM yaitu meliputi pemeriksaan fisik bayi, suhu, pemberian imunisasi, kesehatan tali pusat, denyut jantung bayi, masalah terkait dengan pemberian ASI, memeriksa kulit bayi, apakah bayi diare, pernah kejang dan lain-lain. ${ }^{4}$

Periode neonatal merupakan periode yang paling kritis dalam fase pertumbuhan dan perkembangan bayi. Kurang baiknya penanganan bayi baru lahir atau neonatal yang tidak sehat akan menyebabkan kelainan yang mengakibatkan kecacatan bahkan kematian. Masa neonatal merupakan masa kritis bagi kehidupan bayi, 2/3 kematian bayi terjadi dalam 4 minggu setelah persalinan dan $60 \%$ kematian bayi baru lahir terjadi dalam waktu 7 hari setelah lahir. ${ }^{5}$

Petugas Surveilans Kesehatan (Gasurkes KIA) merupakan petugas kontrak yang diangkat oleh Dinas Kesehatan Kota Semarang dengan kriteria latar belakang pendidikan kebidanan baik lulusan pendidikan Diploma III dan IV Kebidanan yang baru lulus atau sudah mempunyai pengalaman kerja, mempunyai STR, surat ijin praktik bidan, sudah mengikuti pelatihan terkait kebidanan, bukan sebagai bidan delima, tidak sebagai bidan praktik mandiri (PMB), tidak sedang hamil, mau ditempatkan di kelurahan di seluruh Kota Semarang. Tugas dari Gasurkes KIA ini tidak sama dengan tugas yang dilakukan oleh bidan koordinator yang ada dipuskesmas, Gasurkes KIA sebagai petugas lapangan yang ada di masyarakat. Untuk pekerjaannya tidak boleh tumpang tindih dengan bidan koordinator yang ada di pelayanan puskesmas.Selama ini tugas pendampingan ibu hamil, ibu nifas dan 
neonatal menjadi tugas pokok dari Gasukes KIA. ${ }^{6}$

Rumusan masalah penelitian ini adalah: Faktor apa saja yang berhubungan dengan praktik Manajemen Terpadu Bayi Muda dalam pelayanan kunjungan neonatal oleh Gasurkes KIA di Kota Semarang.

\section{Metode}

Jenis penelitian ini adalah kuantitatif dengan menganalisis hubungan antara variabel bebas dan variabel terikat melalui pengujian hipotesis. Metode pendekatan yang digunakan adalah cross sectional yaitu melakukan pengumpulan data yang menyangkut variabel bebas dan variabel terikat pada saat yang bersamaan atau sekaligus. Analisis data menggunakan uji regresi logistik. ${ }^{7}$

\section{Hasil}

Hasil penelitian didapatkan seluruh petugas surveilans kesehatan ibu dan anak (Gasurkes KIA) mempunyai rata-rata umur 27,06 tahun, dan seluruhnya (100\%) berstatus kepegawaian NON ASN, serta sebagian besar berpendidikan setingkat DIII sebanyak 75 orang $(89.3 \%)$. Sebagian besar Gasurkes KIA sebanyak 80 orang $(95,2 \%)$ sudah pernah mengikuti pelatihan di luar Pelatihan MTBM/MTBS, dan pelatihan yang paling banyak diikuti adalah APN atau Asuhan Persalinan Normal sebanyak 80\%, dan PPGDON sebanyak 41,3\%. Seluruh petugas surveilans kesehatan ibu dan anak (Gasurkes KIA) sebanyak 84 orang (100\%), belum pernah mengikuti pelatihan MTBM/MTBS, namun sebagian besar diantaranya sebanyak 64 orang $(76,2 \%)$ sudah pernah mengikuti pembekalan MTBM.

Sebagian besar Gasurkes berpengetahuan kurang, mempunyai masa kerja antara 0-3 tahun, sebagian besar mempunyai sikap mendukung, mempunyai beban kerja normal dengan ketersediaan fasilitas / alat kurang lengkap, mempunyai sistem pencatatan lengkap, supervisi bidan koordinator masuk kategori kurang, reward atau penghargaan kepala puskesmas masuk kategori tidak ada serta praktik manajemen terpadu bayi muda (MTBM) sebagian besar baik.

Tabel. 1.Hasil analisis Bivariat Faktor yang berhubungan dengan praktik manajemen terpadu bayi muda (MTBM)

\begin{tabular}{|c|c|c|c|c|c|c|c|c|c|}
\hline \multirow{3}{*}{ No } & \multirow{3}{*}{ Variabel } & \multicolumn{4}{|c|}{ Praktik MTBM } & \multirow{2}{*}{\multicolumn{2}{|c|}{ Jumlah }} & \multirow[t]{3}{*}{ p value } & \multirow[t]{3}{*}{ OR (95\% CI) } \\
\hline & & \multicolumn{2}{|c|}{ Kurang } & \multicolumn{2}{|c|}{ Baik } & & & & \\
\hline & & $\mathbf{n}$ & $\%$ & $\mathbf{n}$ & $\%$ & $\mathbf{n}$ & $\%$ & & \\
\hline \multirow[t]{3}{*}{1} & Pengetahuan & & & & & & & \multirow{3}{*}{$0,039 *$} & \multirow{3}{*}{$\begin{array}{c}\mathrm{OR}=4,407 \\
(1,174-16,549)\end{array}$} \\
\hline & Kurang & 28 & 43,8 & 36 & 56,3 & 64 & 100 & & \\
\hline & Baik & 3 & 15,0 & 17 & 85,0 & 20 & 100 & & \\
\hline \multirow[t]{3}{*}{2} & Masa Kerja & & & & & & & \multirow{3}{*}{$0,015^{*}$} & \multirow{3}{*}{$\begin{array}{c}\mathrm{OR}=6,847 \\
(1,461-32,088)\end{array}$} \\
\hline & $0-3$ tahun & 29 & 44,6 & 36 & 55,4 & 65 & 100 & & \\
\hline & $>3$ tahun & 2 & 10,5 & 17 & 89,5 & 19 & 100 & & \\
\hline \multirow[t]{3}{*}{3} & Sikap & & & & & & & \multirow{3}{*}{$0,019^{*}$} & \multirow{3}{*}{$\begin{array}{c}\mathrm{OR}=4,571 \\
(1,391-15,022)\end{array}$} \\
\hline & Kurang mendukung & 10 & 66,7 & 5 & 33,3 & 15 & 100 & & \\
\hline & mendukung & 21 & 30,4 & 48 & 69,6 & 69 & 100 & & \\
\hline \multirow[t]{3}{*}{4} & Beban kerja & & & & & & & \multirow{3}{*}{$0,047^{*}$} & \multirow{3}{*}{$\begin{array}{c}\mathrm{OR}=6,120 \\
(1,152-32,521)\end{array}$} \\
\hline & Lebih dari batas & 6 & 75,0 & 2 & 25,0 & 8 & 100 & & \\
\hline & Dalam batas & 25 & 32,9 & 51 & 67,1 & 76 & 100 & & \\
\hline \multirow[t]{3}{*}{5} & Ketersediaan Alat & & & & & & & \multirow{3}{*}{0,739} & \multirow{3}{*}{$\begin{array}{c}\mathrm{OR}=1,659 \\
(0,406-6,785)\end{array}$} \\
\hline & Kurang Lengkap & 28 & 38,4 & 45 & 61,6 & 73 & 100 & & \\
\hline & Lengkap & 3 & 27,3 & 8 & 72,7 & 11 & 100 & & \\
\hline
\end{tabular}




\begin{tabular}{|c|c|c|c|c|c|c|c|c|c|}
\hline 6 & $\begin{array}{l}\text { Sistem Pencatatan } \\
\text { Kurang Lengkap } \\
\text { Lengkap }\end{array}$ & $\begin{array}{c}22 \\
9\end{array}$ & $\begin{array}{l}53,7 \\
20,9\end{array}$ & $\begin{array}{l}19 \\
34\end{array}$ & $\begin{array}{l}46,3 \\
79,1\end{array}$ & $\begin{array}{l}41 \\
43\end{array}$ & $\begin{array}{l}100 \\
100\end{array}$ & $0,004 *$ & $\begin{array}{c}\mathrm{OR}=4,374 \\
(1,679-11,395)\end{array}$ \\
\hline \multirow[t]{3}{*}{7} & $\begin{array}{l}\text { Supervisi Bikor } \\
\text { dan Dinkes }\end{array}$ & & & & & & & & \multirow{3}{*}{$\begin{array}{c}\mathrm{OR}=3,690 \\
(1,226-11,109)\end{array}$} \\
\hline & Kurang & 26 & 45,6 & 31 & 54,4 & 57 & 100 & \multirow{2}{*}{$0,031^{*}$} & \\
\hline & Baik & 5 & 18,5 & 22 & 81,5 & 27 & 100 & & \\
\hline \multirow[t]{3}{*}{8} & Penghargaan/Reward & & & & & & & \multirow{3}{*}{1,000} & \multirow{3}{*}{$\begin{array}{c}\text { OR }=1,064 \\
(0,322-3,517)\end{array}$} \\
\hline & Tidak Ada & 26 & 37,1 & 44 & 62,9 & 70 & 100 & & \\
\hline & Ada & 5 & 35,7 & 9 & 64,3 & 14 & 100 & & \\
\hline
\end{tabular}

Keterangan: * = Signifikan 5\%

Hasil analisis bivariat faktor yang berhubungan dengan praktik MTBM oleh Gasurkes KIA adalah pengetahuan, masa kerja, sikap, beban kerja, sistem pencatatan dan supervisi Bidan Koordinator dan Dinkes.
Faktor yang tidak berhubungan dengan praktik MTBM oleh Gasurkes KIA adalah ketersediaan alat dan penghargaan.

Tabel 2. Hasil Analisis Multivariat Regresi Logistik

\begin{tabular}{clcccc}
\hline Tahap & \multicolumn{1}{c}{ Variabel } & Nilai P & OR & \multicolumn{2}{c}{ CI 95\% } \\
\cline { 5 - 6 } Reg.1 & & & & Min & Maks \\
& Masa Kerja & $0,027^{*}$ & 6,756 & 1,245 & 36,659 \\
& Pengetahuan & 0,061 & 4,939 & 0,930 & 26,234 \\
& Sikap & 0,040 & 4,335 & 1,072 & 17,532 \\
& Beban kerja & 0,129 & 5,479 & 0,610 & 49,207 \\
& Sistem Pencatatan & 0,083 & 2,853 & 0,872 & 9,334 \\
& Supervisi Bikor & 0,579 & 1,479 & 0,372 & 5,878 \\
Reg.2 & Masa Kerja & $0.028^{*}$ & 6.623 & 1.231 & 35.649 \\
& Pengetahuan & 0.050 & 5.216 & 0.997 & 27.280 \\
& Sikap & $0.037^{*}$ & 4.409 & 1.093 & 17.784 \\
& Beban kerja & 0.104 & 6.194 & 0.686 & 55.970 \\
Reg.3 & Sistem Pencatatan & $0.030^{*}$ & 3.297 & 1.122 & 9.687 \\
& Masakerja & $0.027^{*}$ & 6.711 & 1.243 & 36.222 \\
& Pengetahuan & 0.064 & 4.297 & 0.920 & 20.076 \\
& Sikap & $0.024^{*}$ & 4.761 & 1.232 & 18.402 \\
Reg.4 & Sistem Pencatatan & $0.015^{*}$ & 3.736 & 1.290 & 10.819 \\
& Masakerja & $0.028^{*}$ & 6.297 & 1.224 & 32.397 \\
& Sikap & $0.030^{*}$ & 4.325 & 1.157 & 16.173 \\
& Sistem Pencatatan & $0.007^{*}$ & 4.175 & 1.483 & 11.752 \\
\hline
\end{tabular}

Hasil analisis multivariat didapatkan tiga variabel yang berhubungan bermakna dengan praktik MTBM. Masa kerja Gasurkes merupakan faktor yang paling dominan dalam menentukan praktik manajemen terpadu bayi muda, disusul oleh sikap dan yang ketiga adalah system pencatatan. Bahwa yang memiliki masa kerja mulai dari 0- 3 tahun berpeluang banyak melakukan praktik manajemen terpadu bayi muda kurang pada saat kunjungan neonatal 6.297 kali dibanding yang masa kerja $>3$ tahun tahun $(\mathrm{p}=0.028 *)$. Responden yang mempunyai sikap kurang mendukung berpeluang melakukan praktik manajemen terpadu bayi muda kurang 4.325 kali dibanding dengan responden yang mempunyai sikap mendukung $(\mathrm{p}=0.030 *)$. Responden yang mempunyai praktik MTBM kurang itu lebih banyak melakukan sistem pencatatan kurang lengkap 4.175 kali dibandingkan dengan yang melakukan sistem pencatatan lengkap $\left(\mathrm{p}=0.007^{*}\right)$. 


\section{Pembahasan}

Hasil analisis multivariat menunjukkan bahwa responden yang memiliki masa kerja 03 tahun mempunyai resiko berpeluang banyak melakukan praktik manajemen terpadu bayi muda kurang 6.297 kali dibanding yang masa kerja > 3 tahun $\left(\mathrm{p}=0,028^{*}\right)$. Dapat dipahami bahwa lama kerja merupakan gambaran pengalaman bidan dalam menguasai programprogram Manajemen Terpadu Bayi Muda. Lebih lama bidan bertugas sebagai Gasurkes KIA maka lebih banyak pengalaman yang didapatkan dan dampak selanjutnya adalah praktik MTBM akan meningkat. Untuk responden yang mempunyai praktik MTBM kategori kurang sebagian besar dengan masa kerja 0-3 tahun (44,6\%), sedangkan yang mempunyai praktik MTBM kategori baik sebagian besar pada Gasurkes KIA yang mempunyai masa kerja 3 tahun (lama) $89,5 \%$. Masa kerja lebih dari 3 tahun terbukti mampu membuat Gasurkes KIA lebih terampil dalam menangani kasus-kasus pada praktik MTBM. Semakin lama Gasurkes KIA bertugas, dapat meningkatkan praktik MTBM lebih baik dibandingkan dengan yang masa kerjanya baru sebentar atau yang baru bertugas sebagai Gasurkes KIA. Bekerja dengan waktu lebih dari tiga tahun sebagai Gasurkes KIA, sudah banyak mendapatkan pengalaman kerja yang dapat dipetik. Semakin lama bidan bekerja sebagai Gasurkes KIA, maka bidan semakin berpengalaman sehingga mampu memberikan bentuk pelayanan yang terbaik terutama program MTBM. Gasurkes KIA yang telah lama bekerja terbukti memiliki kemampuan lebih baik dalam memberikan pelayanan pada ibu hamil, ibu nifas maupun neonatal terutama pada saat kunjungan neonatal ke rumah menggunakan Manajemen Terpadu Bayi Muda (MTBM).

Faktor kedua yang dapat mempengaruhi praktik MTBM setelah masa kerja adalah sikap Gasurkes KIA. Hasil analisis menunjukkan bahwa Gasurkes KIA yang memiliki sikap kurang mendukung mempunyai resiko 4,325 kali lebih banyak melakukan praktik manajemen terpadu bayi muda kurang dibanding yang mempunyai sikap mendukung $\left(\mathrm{p}=0,030^{*}\right)$.
Gasurkes KIA yang mempunyai praktik MTBM kurang, lebih banyak mempunyai sikap kurang atau tidak mendukung, Gasurkes KIA yang memiliki praktik MTBM baik, lebih banyak mempunyai sikap mendukung atau sikap baik. Berdasarkan temuan ini maka ada kecenderungan bahwa sikap berhubungan positif dengan praktik MTBM. Semakin kurang mendukung sikap Gasurkes KIA, maka semakin kurang praktik MTBM yang dimiliki Gasurkes KIA, sebaliknya semakin mendukung sikap Gasurkes KIA terhadap program, maka semakin baik praktik MTBM. Sikap kurang mendukung dapat ditunjukkan dengan potensi yang dimiliki kurang mendukung Gasurkes KIA dalam mendapatkan prestasi kerja yang optimal dan Gasurkes KIA merasakan kebosanan dan jenuh terhadap pekerjaan yang monoton dilakukan selama ini. Gasurkes KIA juga yakin apabila bekerja dengan penuh konsentrasi, maka Gasurkes KIA akan mampu menjalankan program dengan baik. Gasurkes KIA menganggap Buku KIA sangat penting sebagai sarana komunikasi dan bahan konseling edukasi ibu bayi dan keluarga.

Melihat hasil penelitian tersebut maka sikap sangat berkaitan dengan pengetahuan dan komunikasi informasi edukasi (KIE) serta ketrampilan konseling yang dimiliki oleh Gasurkes KIA. Hasil penelitian diperoleh bahwa sikap yang mendukung Gasurkes KIA terhadap program MTBM, ditunjukkan dengan rasa tanggung jawab atas pelaksanaan program MTBM. Menurut Gasurkes KIA bahwa praktik MTBM itu membutuhkan konsentrasi tinggi dan tersendiri sehingga mampu menjalankan praktik dengan baik. Adanya anggapan Gasurkes KIA didalam melakukan kunjungan neonatal kurang teliti akan berakibat fatal terhadap bayi. Gasurkes KIA juga setuju bahwa pekerjaan yang dilakukan bersifat kreatif dan inovatif.

Maka diperlukan sosialisasi pentingnya buku KIA dan lebih sering memberikan refreshing kepada Gasurkes KIA untuk mengingatkan komitmen bersama dalam mendukung program MTBM saat melakukan kunjungan neonatal. Dan untuk mengurangi kebosanan dari Gasurkes KIA yang sudah bekerja lebih dari tiga tahun diperlukan rotasi 
kerja untuk meningkatkan pengalaman yang lebih bervariatif.

Sesuai dengan teori yang disampaikan oleh Lawrence Green bahwa faktor-faktor yang mempengaruhi perilaku seseorang diantaranya adalah pengetahuan, sikap, kepercayaan, nilainilai yang dimiliki, dan persepsi. Sikap mendukung dapat membentuk perilaku kerja tinggi apabila didahului minat yang tinggi pula. Minat tinggi Gasurkes KIA ditunjukkan dengan tekad sungguh-sungguh akan bertanggung jawab terhadap kesuksesan pelaksanaan program MTBM.

Faktor ketiga yang dapat mempengaruhi praktik MTBM setelah sikap adalah sistem pencatatan dan pelaporan. Hasil analisis menunjukkan bahwa Gasurkes KIA yang memiliki sitem pencatatan pelaporan kurang lengkap mempunyai resiko 4,175 kali lebih banyak melakukan praktik manajemen terpadu bayi muda kurang dibanding yang mempunyai sistem pencatatan lengkap ( $\left.\mathrm{p}=0,007^{*}\right)$.

Dari hasil penelitian ini ditemukan sistem pencatatan yang masih kurang lengkap yaitu Gasurkes KIA terlewatkan bahkan tidak melakukan pencatatan pelayanan kesehatan neonatal di buku KIA pada saat melakukan kunjungan neonatal dengan MTBM. Apabila pencatatan dan pelaporanya ada yang tidak dilakukan atau kurang lengkap maka otomatis akan berpengaruh terhadap praktik MTBM karena didalam penilaian pendekatan Manajemen Terpadu Bayi Muda banyak terkait pengisian pencatatan dan pelaporan ketika melakukan kunjungan neonatal yang ada di buku KIA. Sistem pencatatan terbukti berpengaruh terhadap praktik MTBM setelah sikap.

Sistem pencatatan dan pelaporan dengan MTBM ini dianggap ribet juga oleh Gasurkes KIA ketika dilapangan karena terlalu banyak perihal temuan yang harus dituliskan pada form-form MTBM yang dibawa dan menuliskan kembali buku KIA yang dimiliki ibu bayi, ini juga dianggap memperlama pelayanan pada saat pendampingan neonatal. Hasil yang sudah diperoleh dalam kunjungan neonatal harus dimasukkan dalam pelaporan Gasurkes KIA secara online melalui SiGasPol dalam waktu 24 jam yang menjadi dalam target penilaian kinerja Gasurkes KIA terkait sistem pencatatan dan pelaporanya. Tentu ini juga akan mempengaruhi dalam melakukan praktik MTBM, karena Gasurkes KIA pada saat kunjungan neonatal akan terfokus pada kecepatan pelaporan yang harus dikirimkan ke dinas kesehatan yang menjadi penilaian kinerja dari Gasurkes KIA tetapi secara kualitas dengan praktik MTBM masih diragukan.

Untuk meningkatkan penilaian kinerja Gasurkes KIA diperlukan evaluasi dan monitoring secara periodik untuk menyempurnakan sistem pencatatan dan pelaporan dengan mengupdate informasi sesuai kebutuhan. Membuat inovasi sitem pencatatan dan pelaporan yang simple untuk mempermudahkan Gasurkes KIA. Target kecepatan pelaporan perlu dikaji lagi yang terpenting adalah penilaian dari kualitas pelayanan kunjungan. Kemudian meningkatkan sosialisasi kepada Gasurkes KIA manfaat dan pentingnya buku KIA.

Sistem pencatatan juga sebagai bukti pencatatan dan pelaporan yang dilakukan oleh Gasurkes KIA dalam mencatat perawatan yang berguna untuk kepentingan pasien, bidan dan tim kesehatan dalam memberikan pelayanan kesehatan dengan dasar komunikasi yang akurat dan lengkap secara tertulis dengan tanggung jawab Gasurkes KIA sebagai seorang bidan.

Sistem pencatatan sebagai dokumentasi kebidanan menjadi penting bagi bidan dalam memberikan asuhan kebidanan serta dalam mengingat kembali riwayat yang terjadi dimasa lalu untuk menelusuri apakah ada permasalahan kesehatan pada bayi untuk bisa dilakukan tindakan yang tepat. Asuhan kebidanan yang diberikan kepada pasien membutuhkan pencatatan dan pelaporan yang dapat digunakan sebagai acuan selanjutnya untuk menghadapi berbagai permasalahan yang dialami oleh pasien untuk menghindari kesalahan agar tidak terulang.

Sistem pencatatan digunakan sebagai suatu keterangan baik tertulis maupun terekam, mengenai data anamnesa melalui wawancara, hasil pemeriksaan fisik, hasil pemeriksaan penunjang (laborat, USG dan sebagainya), analisa (diagnosa), perencanaan dan pelaksanaan serta evaluasi, tindakan, pengobatan. Jadi sistem pencatatan yang baik 
akan mendukung praktik Gasurkes KIA tentang MTBM semakin lebih baik.

\section{Masa Kerja Mempengaruhi Praktik Manajemen Terpadu Bayi Muda (MTBM) KIA di Kota Semarang}

Berdasarkan hasil penelitian diperoleh bukti bahwa ada hubungan antara masa kerja dengan praktik manajemen terpadu bayi muda (MTBM) oleh Gasurkes KIA di Kota Semarang dengan $p$ value sebesar 0,015. Gasurkes KIA yang mempunyai praktik MTBM kurang itu lebih banyak pada Gasurkes KIA dengan masa kerja 0-3 tahun, sedangkan Gasurkes KIA yang memiliki praktik MTBM baik didapat dari Gasurkes KIA yang mempunyai masa kerja lama > 3 tahun. Dan dari hasil penelitian ini diperoleh bahwa Gasurkes KIA yang mempunyai masa kerja 0-3 tahun berisiko 6,847 kali lebih tinggi melakukan praktik MTBM kurang dibandingkan yang sudah mempunyai masa kerja $>3$ tahun.

Masa kerja yang dimaksud pada penelitian ini adalah lama kerja bidan yang dihitung sejak pertama bertugas sebagai Gasurkes sampai dilakukan penelitian.

Sesuai dengan hasil analisis mutivariat pada penelitian ini bahwa masa kerja mempunyai pengaruh paling kuat dan lebih dominan terhadap praktik MTBM. bisa dikatakan bahwa semakin lama masa kerja Gasurkes KIA maka praktik MTBM semakin baik. Karena dengan masa kerja yang lama tentunya berkaitan dengan pengalaman yang diperoleh Gasurkes KIA lebih banyak dalam praktik menangani permasalahan, kasus lebih banyak dan bervariatif.. Sehingga pengetahuan praktisnya dalam memberikan pelayanan kunjungan neonatal bertambah trampil. Semakin banyak melakukan pengamatan dan pengalaman secara langsung maka praktik MTBM yang pada saat kunjungan neonatal menjadi lebih baik, mudah tidak menjadi beban dalam melaksanakan praktik MTBM.

Hasil penelitian ini konsisten dengan penelitian sebelumnya bahwa masa kerja berhubungan dengan kinerja bidan dalam kunjungan neonatal. ${ }^{8,9}$ Masa kerja yang lama menjadikan semakin banyak bidang tugas yang dikuasai oleh bidan. Semakin lama bekerja, kemampuan dan pengetahuan praktisnya akan bertambah. Pengetahuan praktis diperoleh melalui pengamatan dan pengalaman langsung. Pengalaman langsung yang diperoleh bidan dalam menangani berbagai persoalan ibu hamil, membuat bidan menjadi lebih terampil sehingga secara otomatis pratiknya semakin baik. Pengalaman menghadapi banyak persoalan ketika menangani pasien menjadikan ketrampilan bidan dalam praktik MTBM semakin baik.$^{10}$

\section{Sikap Mempengaruhi Praktik Manajemen Terpadu Bayi Muda (MTBM) KIA di Kota Semarang}

Berdasarkan hasil penelitian yang sudah dilakukan ditemukan bahwa ada hubungan antara sikap dengan praktik manajemen terpadu bayi muda (MTBM) oleh Gasurkes KIA di Kota Semarang dengan $\mathrm{p}$ value sebesar 0,019 ( $\mathrm{p}$ value < 0,05). Gasurkes yang mempunyai praktik MTBM kurang, lebih banyak mempunyai sikap kurang mendukung sebanyak 66,7 \% disbanding yang memiliki sikap mendukung sebesar 30,4\%. Berdasarkan temuan ini maka ada kecenderungan bahwa sikap berhubungan positif dengan praktik MTBM. Jadi semakin kurang mendukung sikap Gasurkes KIA, maka semakin kurang praktik MTBM yang dimiliki Gasurkes, sebaliknya semakin mendukung sikap Gasurkes KIA, maka semakin baik praktik MTBM.

Hasil penelitian diperoleh bahwa sikap yang mendukung Gasurkes KIA terhadap program MTBM, ditunjukkan dengan rasa tanggung jawab atas pelaksanaan program MTBM. Menurut gasurkes KIA bahwa praktik MTBM itu membutuhkan konsentrasi tinggi dan tersendiri serta responden mampu menjalankan praktik dengan baik. Anggapan gasurkes apabila dalam kunjungan neonatal kurang teliti akan berakibat fatal terhadap bayi. Gasurkes KIA juga setuju bahwa pekerjaan yang dilakukan bersifat kreatif dan inovatif. Sikap Gasurkes KIA yang semakin mendukung terhadap program MTBM maka praktiknya akan semakin baik. Sikap Gasurkes yang kurang mendukung terhadap program MTBM maka praktiknya akan semakin buruk. Sikap kurang mendukung berisiko 4,571 kali lipat melakukan praktik MTBM kurang. 
Hasil penelitian diperoleh bahwa sikap yang mendukung Gasurkes KIA terhadap program MTBM, ditunjukkan dengan rasa tanggung jawab atas pelaksanaan program MTBM. Menurut gasurkes KIA bahwa praktik MTBM itu membutuhkan konsentrasi tinggi dan tersendiri serta responden mampu menjalankan praktik dengan baik. Anggapan gasurkes apabila dalam kunjungan neonatal kurang teliti akan berakibat fatal terhadap bayi. Gasurkes KIA juga setuju bahwa pekerjaan yang dilakukan bersifat kreatif dan inovatif. Sikap Gasurkes KIA yang semakin mendukung terhadap program MTBM maka praktiknya akan semakin baik. Sikap Gasurkes yang kurang mendukung terhadap program MTBM maka praktiknya akan semakin buruk. Sikap kurang mendukung berisiko 4,571 kali lipat melakukan praktik MTBM kurang.

Berdasarkan hasil penelitian ditemukan bukti bahwa ada hubungan antara sikap dengan praktik manajemen terpadu bayi muda (MTBM) oleh Gasurkes KIA di Kota Semarang dengan $p$ value sebesar 0,030. Gasurkes yang mempunyai praktik MTBM kurang, lebih banyak mempunyai sikap kurang atau tidak mendukung, Gasurkes yang memiliki praktik MTBM baik, lebih banyak mempunyai sikap mendukung atau baik. Berdasarkan temuan ini maka ada kecenderungan bahwa sikap berhubungan positif dengan praktik MTBM. Jadi semakin kurang mendukung sikap Gasurkes KIA, maka semakin kurang praktik MTBM yang dimiliki Gasurkes, sebaliknya semakin mendukung sikap Gasurkes KIA terhadap program, maka semakin baik praktik MTBM Gasurkes.

Sikap bermula dari perasaan suka atau tidak suka,atau kecenderungan seseorang dalam merespons sesuatu objek. Sikap juga sebagai ekspresi dari nilai-nilai atau pandangan hidup yang dimiliki oleh seseorang. Sikap terdiri dari tiga komponen, yakni afektif, kognitif, dan konatif atau perilaku. Komponen kognitif adalah kecenderungan untuk berperilaku atau berbuat dengan cara-cara tertentu berkenaan dengan kehadiran objek. Sikap mendukung pada tingkatan awal ditunjukkan dengan perhatian Gasurkes terhadap MTBM, kemudian merespon dengan memberikan jawaban apabila ditanya, mengerjakan, dan menyelesaikan tugas yang diberikan adalah suatu indikasi dari sikap mendukung. Suatu usaha untuk menjawab pertanyaan atau mengerjakan tugas yang diberikan, terlepas dari pekerjaan itu benar atau salah berarti bahwa orang menerima ide tersebut. Pada tingkatan yang lebih tinggi maka sikap mendukung ditunjukkan dengan mengajak orang lain untuk mengerjakan atau mendiskusikan suatu masalah. Sikap mendukung pada tingkatan yang lebih tinggi lagi adalah bertanggung jawab atas segala sesuatu yang sudah menjadi pilihan dengan segala resiko merupakan sikap yang paling tinggi. ${ }^{11}$

Hal ini dapat dimengerti bahwa petugas yang mempunyai sikap baik akan cenderung baik dalam melakukan praktik kunjungan neonatal dengan menggunakan pendekatan manajemen terpadu bayi muda (MTBM), sesuai dengan teori perilaku yang mengatakan bahwa perilaku seseorang terhadap sesuatu akan sesuai dengan tingkat pemahaman terhadap sesuatu tersebut. ${ }^{12}$ Hasil penelitian konsisten dengan penelitian terdahulu yang menunjukkan adanya pengaruh antara sikap terhadap penatalaksanaan manajemen MTBS pada petugas kesehatan di Puskesmas Kabupaten Boyolali. ${ }^{13}$

Penelitian ini juga sejalan dengan pendapat peneliti sebelumnya bahwa perilaku seseorang dapat dipengaruhi oleh sikap, pengetahuan dan ketrampilan yang dimiliki serta dalam hal tertentu oleh material yang tersedia. Sikap dipengaruhi oleh beberapa hal diantaranya seperti pengalaman pribadi, kebudayaan orang lain yang dianggap penting oleh media massa, institusi atau lembaga pendidikan dan pendidikan agama serta emosi dari dalam diri atau individu. Sikap tidak dibawa orang sejak dari lahir, melainkan dibentuk sepanjang perkembangannya, sikap ini dapat berubah, oleh karena itu sikap dapat dipelajari, sikap tidak berdiri sendiri melainkan selalu berkaitan dengan suatu objek. ${ }^{12}$ 
Sistem Pencatatan Mempengaruhi Praktik Manajemen Terpadu Bayi Muda (MTBM) KIA di Kota Semarang

Berdasarkan hasil penelitian menunjukkan bahwa ada hubungan antara sistem pencatatan dengan praktik manajemen terpadu bayi muda (MTBM) yang dilakukan oleh Gasurkes KIA di Kota Semarang dengan $p$ value $=0,004(p$ value< 0,05). Gasurkes yang mempunyai praktik MTBM kurang, lebih banyak mempunyai sistem pencatatan kurang lengkap, Gasurkes yang memiliki praktik tentang MTBM baik, lebih banyak mempunyai sistem pencatatan lengkap. Hasil penelitian ini membuktikan bahwa terdapat hubungan positif antara sistem pencatatan oleh Gasurkes KIA dengan praktik manajemen terpadu bayi muda (MTBM). Jadi semakin lengkap sistem pencatatan, maka semakin baik praktik MTBM, sebaliknya sistem pencatatan semakin kurang lengkap, maka semakin buruk atau kurang praktik MTBM, atau dengan kata lain Gasurkes KIA yang mempunyai sistem pencatatan kurang lengkap, berisiko 4,374 kali lebih tinggi untuk mempunyai praktik MTBM kurang dibandingkan dengan sistem pencatatan lengkap.

Pencatatan atau pelaporan menggunakan sistem gasurkes pelaporan online ( $\mathrm{Si}$ Gas pol). Hasil pemeriksaan neonatal di catat di buku KIA, untuk pencatatan dan pelaporan Gasurkes KIA sudah paperless. Untuk kuesioner sudah ada di sistem online dan sudah ada ceklist terkait kunjungan neonatal sesuai dengan manajemen terpadu bayi muda.Sistem pencatatan merupakan hasil pemeriksaan $\mathrm{KN}$ yang dilakukan pencatatan di buku KIA dan pelaporan online dengan SiGaspol sesuai target waktu. Sistem pencatatan semakin baik, maka praktik MTBM juga baik, sebaliknya sistem pencatatan semakin kurang baik, maka praktik MTBM juga kurang baik.

Hasil penelitian diketahui sistem pencatatan lengkap disebabkan karena setiap melakukan kunjungan rumah ibu nifas dan neonatal, Gasurkes melakukan pencatatan dan pelaporan on line dengan SiGaspol. Pada setiap pemeriksaan kunjungan neonatal Gasurkes selalu melakukan pelaporan secara sistematik setiap bulan. Format pencatatan hasil pemeriksaan kunjungan neonatal sudah sesuai dengan MTBM. Pencatatan hasil pemeriksaan kunjungan neonatal dengan MTBM dilakukan setelah selesai melakukan kunjungan rumah. Pelaporan hasil pemeriksaan kunjungan ibu hamil, nifas dan neonatal dilakukan dalam 24 jam. Hasil penelitian ditemukan sistem pencatatan yang masih kurang lengkap yaitu Gasurkes tidak melakukan pencatatan pelayanan kesehatan neonatal di buku KIA pasa saat melakukan kunjungan neonatal dengan MTBM. Pada penelitian ini ditemukan sistem pencatatan lengkap masih lebih banyak dibandingkan sistem pencatatan kurang atau tidak lengkap. Sistem pencatatan terbukti berpengaruh terhadap praktik MTBM..

Sistem pencatatan sebagai bukti pencatatan dan pelaporan yang dimiliki oleh Gasurkes dalam melakukan catatan perawatan yang berguna untuk kepentingan pasien, bidan dan tim kesehatan dalam memberikan pelayanan kesehatan dengan dasar komunikasi yang akurat dan lengkap secara tertulis dengan tanggung jawab Gasurkes sebagai seorang bidan.

Sistem pencatatan sebagai dokumentasi kebidanan sangat penting bagi bidan dalam memberikan asuhan kebidanan. Hal ini karena asuhan kebidanan yang diberikan kepada klien membutuhkan pencatatan dan pelaporan yang dapat digunakan sebagai acuan selanjutnya untuk menghadapi berbagai permasalahan yang dialami oleh pasien, untuk menghindari kesalahan agar tidak terulang.

Sistem pencatatan berperan sebagai pengumpul, penyimpan, dan penyebarluasan informasi guna mempertahankan sejumlah fakta yang penting secara terus menerus pada suatu waktu terhadap sejumlah kejadian ${ }^{72}$ Sistem pencatatan digunakan sebagai suatu keterangan, baik tertulis maupun terekam, mengenai data subyektif yang diambil dengan anamnesa (wawancara), hasil pemeriksaan fisik, hasil pemeriksaan penunjang, analisa (diagnosa), perencanaan dan pelaksanaan serta evaluasi, tindakan medis, pengobatan yang diberikan kepada klien baik rawat jalan maupun rawat inap, serta pelayanan gawat darurat ${ }^{8}$ Jadi sistem pencatatan yang baik akan mendukung praktik Gasurkes KIA tentang MTBM semakin lebih baik. 


\section{Kesimpulan}

Bahwa variabel-variabel yang secara analisis bivariat berhubungan dengan praktik Manajemen Terpadu Bayi Muda (MTBM) adalah variabel pengetahuan, masa kerja, sikap, beban kerja, sistem pencatatan pelaporan serta variabel supervisi bidan koordinator dan dinas kesehatan. Dan variabel yang tidak ada hubungan dengan Manajemen Terpadu Bayi Muda (MTBM) adalah variabel keterbatasan fasilitas/peralatan dan reward / penghargaan dari kepala puskesmas. Sedangkan dari semua variabel yang berhubungan tersebut mempunyai pengaruh sangat dominan atau pengaruhnya yang paling kuat adalah variabel masa kerja diikuti variabel sikap dan variabel sistem pencatatan dan pelaporan.

\section{Ucapan Terimakasih}

Terimakasih kepada teman-teman Bidan Praktik Mandiri di wilayah Kota Semarang yang sudah berkontribusi dalam pengumpulan data. Dan teman-teman Gasurkes KIA kelurahan di Kota Semarang yang telah membantu dan bersedia sebagai responden pada penelitian ini.

\section{Daftar Pustaka}

1. Anonim. 2017. Kesehatan Dalam Kerangka Sustainable Development Goals (SDGs). Jakarta: Kementrian Kesehatan Republik Indonesia..

2. Anonim. 2018. Profil Kesehatan Kota Semarang: Dinas Kesehatan Kota Semarang.

3. Anonim. 2012. Buku Saku Pelayanan Kesehatan Neonatal Esensial. Jakarta: Direktorat Bina Kesehatan Anak Kemenkes.

4. Anonim. 2013. Manajemen Terpadu Balita Sakit Modul 1, 5, 7, dan Buku Bagan. Jakarta: Kemenkes RI.
5. Jamhariyah. 2013. Analisis Kinerja Bidan desa dalam Pelayanan Neonatus di Puskesmas Kab Lumajang. Jurnal Ilmu Kesehatan Masy. 9 (1).

6. Anonim. 2020. Surat perihal Pendampingan Ibu Hamil dan Nifas. Semarang: Dinas Kesehatan Kota Semarang.

7. Soekidjo Notoatmodjo. 2018. Metodologi Penelitian Kesehatan. Jakarta : Rineka Cipta.

8. Suryaningtyas, F. 2012. Faktor terkait kinerja bidan desa dalam kunjungan neonatal di Kabupaten Pati Tahun 2012. Jurnal Penelitian Kesehatan Suara Forikes. 4 (4): 180.

9. Fountein-Kuipers, Y.J., Bude, L., Ausems, M., D. \& Vries, R., Nieuwenhuijze, M. J. 2014. Dutch midwives' behavioural intention of antenatal and factor influencing these intention: An explanatory survey. Midwifery Journal. 30 (2): 234- 241.

10. Anonim. 2014. Materi Pelatihan Implementasi Kurikulum 2013. Kementrian Pendidikan dan Kebudayaan RI: Jakarta.

11. Notoatmojo, S. 2012. Promosi Kesehatan dan Perilaku Kesehatan. Jakarta : Penerbit Rineka Cipta.

12. Notoatmodjo S. 2003. Pendidikan dan Perilaku Kesehatan. Jakarta: PT. Asdi Mahasatya.

13. Hastuti, S. 2010. Pengaruh Pengetahuan, Sikap dan Motivasi terhadap Penatalaksanaan MTBS pada Petugas Kesehatan di Puskesmas Kabupaten Boyolai, Tesis: Universitas Sebelas Maret Surakarta. 